\title{
Introduction to the Handbook on Green Growth*
}

\section{Roger Fouquet}

\section{THE PURSUIT OF GREENER GROWTH}

By 2050, the global economy is expected to double (OECD, 2018). Without a transition in the energy system, this expanding world economy will emit levels of carbon dioxide that leave little hope of halting climate change. It will also be putting increasing pressure on other planetary boundaries, including water resources, soil degradation and biodiversity. Angel Gurria, the Secretary-General of the $\operatorname{OECD~(2012,~p.1),~stressed~that~'continued~}$ degradation and erosion of natural environmental capital is expected to 2050, with the risk of irreversible changes that could endanger two centuries of rising living standards'.

This risk is particularly alarming in light of the political tensions generated by the weakness of economic growth in OECD countries over the last decade. Following the global economic and financial crisis of 2008, economic growth has become a key priority for governments around the world. This sentiment has also pushed environmental stewardship down the list of priorities among much of the electorate and many politicians around the world. Yet, without coordinated political will, and carefully directed incentives, global markets will fail to take account of their environmental impacts, potentially triggering a downward spiral of environmental damage and economic hardships. Thus, the global economy stands at a critical juncture: it either achieves an energy transition and follows an environmentally-friendly growth path, or it risks locking itself onto an unsustainable trajectory.

The pursuit of 'green growth' offers the opportunity for economies to expand and develop while still protecting their environment. One example of the attempt to dovetail these two objectives is the Green New Deal, which has gained traction in the USA in the last year. This political movement seeks to create jobs in part through investment in green infrastructure. The combination of economic and electrical development wants to replicate Franklin D. Roosevelt's stimulus package of the 1930s - this time trying to generate economic, social and environmental transformation.

In fact, this 'green growth' (or 'clean growth') paradigm has been seen as offering the possibility of creating a 'new industrial revolution'. Lord Stern anticipates that

the new industrial revolution and the transition to low-carbon growth constitute a very attractive path. It is likely to bring two or three decades of innovative and creative growth and large and growing markets for the pioneers. Low-carbon growth, when achieved, will be more energysecure, cleaner, safer and more bio-diverse than its predecessors. (Stern, 2009)

Since 2008, a window of opportunity has been created to try to address both challenges - of economic growth and environmental protection - as an integrated package of policies

* Support for this project from the Grantham Foundation for the Protection of the Environment and the UK Economic and Social Research Council (ESRC), through its support of the Centre for Climate Change Economics and Policy (CCCEP), is gratefully acknowledged. 
(Bowen and Hepburn, 2014). Such a promising outlook triggered a flurry of initiatives and ambitious policies. Some followed swiftly after the financial crisis of 2008, and sought to generate a green stimulus to the economy (Barbier, 2010). At the end of the last decade, more than $\$ 430$ billion, or around 15 per cent of the $\$ 2.8$ trillion dedicated for stimulating the economy globally, were related to climate change (Robins et al., 2009). Since then, many governments around the world have sought to introduce additional green or clean industrial policies and programmes.

Yet, despite more than a decade of experience, the potential of integrated economic and environmental policies to improve competitiveness and generate transformative economic growth and development is still poorly understood. For instance, the debate has made us pause and think about the value of economic growth itself and about the type of growth that is desirable. Also, it is important to consider further: when do economic growth and environmental policies act as complements or as substitutes? What are the key factors that will achieve green growth? What will be the multiple impacts of green growth? Also, given that some green transformations are underway, it is important to learn lessons, identifying the characteristics and challenges of actually trying to follow such a path. Finally, it is also important to place the environmental dimensions of economic growth within the wider context of current structural transformations. Yet, before doing so, it is worth reviewing the long run relationships between economic growth and natural capital, and the challenges of achieving 'green growth'.

\section{LONG RUN ECONOMIC DEVELOPMENT AND NATURAL CAPITAL}

Economic growth is a fundamental strategy for poverty alleviation and the raising of living standards (Deaton, 2013). It has also been argued that economic growth has engendered major social reforms and, at sufficient levels of income, environmental protection (Friedman, 2005). Thus, there are strong grounds for seeking to promote economic growth provided it achieves sustainable development.

Traditionally, long run economic growth has been associated with creating institutions to protect economic agents' rights to produce, exchange and consume (North, 1990), developing a culture of enterprise and commerce (McCloskey, 2006), incorporating ideas and innovation that will improve production, exchange and consumption (Mokyr, 2002), and ensuring the availability and dynamic incentives to minimise prices of all factors of production, as well as barriers to trade. Critical to generating economic growth is the process of shifting factors of production from low- to high-productivity activities and raising GDP per capita (Rodrik, 2013). Nevertheless, economic development reflects improvements in human economic, political and social well-being, in part but not exclusively dedicated to raising individual incomes, poverty alleviation, raising access to basic public amenities and services, such as water, energy sources, and environmental quality, as well as market conditions and opportunities, and social conditions, such as justice, human rights and education (Sen, 1999).

A key feature of past successful economies in the long run has been their ability to transform - to continue to grow and develop economically by investing returns in valuable and productive activities. While numerous explanations for economic stagnation 
and decline exist, a recurring theme, as Toynbee (1946), Olson (1982) and more recently Acemoglu and Robinson (2012) have argued, is the role played by powerful vested interests. They have been central in limiting the potential for economies and societies to transform, and were a likely source of stagnation. The incumbents, those that had gained power when their economy grew, may not have had sufficient incentives to strive for structural change. During the status quo, they were in a position of primacy. Change, especially structural change, may have put their position of power in jeopardy. However, these incentives hindered the potential for change and to create new periods of growth.

Indeed, Barbier (2013) proposes that many powerful pressure groups that benefit from the economic status quo are hindering political and economic transformations that are required to address climate change. In other words, vested interests raise a potential threat to the long run success of our current economic system by thwarting attempts to steward the natural environment. This failure to transform due to the structures of power can be linked with Diamond's (2005) explanation for economic and societal collapse due to the exploitation of resources in non-sustainable ways and to climate change.

Certainly, as mentioned earlier, an important factor that can hinder the momentum of economic growth is a failure to govern the existing natural capital properly. Early economists, such as Malthus (1798) and Ricardo (1817), had identified the critical role natural capital (in particular, land) played in traditional economic activity. However, during the nineteenth century, the successful transformation of Western economies through industrialisation focused economists' attention on the importance of labour and physical capital, as exemplified by Solow's (1956) growth model. As a result, for a long time, economists - and economies - tended to forget about other factors of production, including natural and human capital.

The 'capitalist instinct' as outlined by the godfather of economic transformation, Schumpeter (1942), has been to make profits from exploiting resources and capital (financial, physical, human or natural). As a reminder, slave and child labour were associated with many European countries into the nineteenth century (Engerman, 1995; Horrell and Humphries, 1995). Over time, civil society realised that this exploitation was socially undesirable behaviour, and economically inefficient in the long run. For instance, while factories may have benefited in the short run from using cheap child labour, the economy and society benefited in the long run from delaying children's entry into the labour market by providing higher levels of education and skills (Goldin and Katz, 1998; Galor, 2011). With the increasing role of human capital in economic development from the end of the nineteenth century, greater concern was given to labour and workers' skills. Equally, dependence on slave labour for production hindered industrial development, trade and economic growth. Nevertheless, realisation did not mean that these systems were easy or quick to substitute (Anderson and Gallman, 1977). It took political pressure on and compensation to slave owners and entrepreneurs for legislation to be passed that abolished slave and child labour and improved adult working conditions. In other words, incentives can lock economies into undesirable systems that require much will, effort and new incentives to be transformed.

Similarly, despite being left in the shadows, natural capital continued to be a vital source of economic growth and development. Certainly, Johnson (1909) noted the importance of 'natural capital' in economic growth early on, but many economists tended to nod in agreement and then put the concept to one side. However, coinciding with the oil price 
shocks of the 1970s, there has been an attempt to incorporate the role of energy in the production function and in models of economic growth (Solow, 1974; Dasgupta and Heal, 1979). Most recently, Acemoglu et al. (2012) explicitly modelled how innovation in the development of dirty (for example, fossil fuels) and clean (for example, renewable) energy sources affected economic growth. Their model identified the crucial role of market size and price effects on the direction of technical change. That is, innovation can be directed towards the larger market (that is, currently fossil fuels) or the more expensive market (that is, until recently, renewable energy). They concluded that the market equilibrium without government involvement would lead to accelerating environmental damage as innovation will tend to be directed towards the technology related to the polluting energy source. This is because, where fossil fuels and renewables are substitutes, the role of market size will dominate. Their model highlighted the costs of delaying the introduction of policies promoting the development of renewable energy that will enable economic growth without generating major external costs, and, thus, avoiding this drag on economic growth.

Looking at the empirical evidence, Cipolla (1962) and Allen (2009) highlighted the critical role energy played in the Industrial Revolution that unfolded in Britain during the eighteenth and nineteenth centuries. Similarly, Wright and Czelusta (2006) showed how, in the USA, resource and, in particular, coal abundance was paramount to its industrialisation process. Stern and Kander (2012) concluded that energy-augmenting technological change played a critical role in the nineteenth- and early twentieth-century economic growth in Sweden. Norway, Canada, Australia and Botswana offer more contemporary cases in which the large-scale use of natural resource generated economic growth (Sanders and Sandvik, 2015; Hillbom, 2015; Ranestad, 2018). In fact, almost all economies' early phase of economic development is founded on the exploitation of natural resources.

Resource-based development is often successful initially, yet limited in the long run (Badia-Miró et al., 2015). Historical evidence, supported by theory (Lundahl, 1998), stresses the vulnerability of resource-based development - and can be seen as an aspect of the resource curse (Auty, 2001). In the late nineteenth and early twentieth centuries, numerous countries, such as Mexico, Venezuela, Chile and Indonesia, failed to shift away from their specialisation in primary exports and manufacture, and suffered the consequences (Badia-Miró and Ducoing, 2015; Rubio-Varas, 2015). Economies can struggle to invest returns in more dynamic and productive sectors - partly due to the aforementioned vested interests favouring the status quo (Bértola, 2015). Much of the explanation for the failure to use natural resources effectively is down to the institutions (Clay, 2010). Nevertheless, in the long run, increasing dependence on natural resource exploitation and the inability to branch out can become a hindrance to economic growth and development in mid-income countries, and can ultimately lead to stagnation and decline (Barbier, 2011).

The history of rubber exploitation exemplifies this risk, and the potential opportunity. Throughout the nineteenth century, the Amazonian region of Brazil became wealthy by producing 90 per cent of the world's rubber (Barham and Coomes, 1994). However, the region failed to adapt its modes of production or effectively invest its returns in alternative sources of economic growth. Following the drop in demand associated with the First World War, the Brazilian rubber industry and the Amazonian region never recovered. In a similar way, Malaysia, which along with Indonesia had come to dominate the global rubber market in the first half of the twentieth century, faced shrinking distribution 
and demand during the Second World War, and subsequently, due to competition from synthetic rubber. While improving productivity, Malaysia was no longer able to rely on rubber revenue for economic growth and development. Instead, it diversified, becoming the world's leader in palm oil production, and, in the 1970s and 1980s, expanded its oil and natural gas industry, as well as developments in manufacturing, such as electronics and textiles (Drabble, 2000). Undoubtedly, Malaysia would have experienced major economic decline without its structural transformation away from its dependence on rubber production.

An important lesson is that natural capital-based growth - that is, heavy exploitation and depletion of primary products or natural resources - should only be a temporary phase in an economy's history. Long run dependence on natural resources is likely to hinder growth potential because of a combination of limited endowments, competition, and the evolution of demand as economies develop, as well as the intensification of the entrenchment and power of vested interest groups. Instead, governments should see natural resources as the initial source of revenue to enable an economy to invest in higher-value goods and services that depend, not on natural resources, but on physical and human capital.

Having said this, policy makers need to remember that the natural environment is the foundation of the economy and should not be weakened or eroded - which is likely to occur in periods of demographic or economic growth. In addition to the resource or provisioning aspects, nature has played a fundamental role in the generation of (renewable) ecosystem services (Barbier, 2005). While it is hard to identify the causal impact of their role in generating economic growth, there has been a growing awareness that nature has provided these public goods, free to use and, therefore, poorly managed by markets. In turn, these market failures and the declining supply of these services have imposed great costs on human economic and social well-being. For example, during the Industrial Revolution, coal production and consumption was responsible for annual external costs of nearly 20 per cent of Britain's GDP, principally due to air pollution (Fouquet, 2011). Air pollution in China in 1995 was estimated to have caused damage equivalent to 9 per cent of GDP (Matus et al., 2012). Similarly, concerns about the impacts of other forms of pollution, particularly related to water and sewage, imposed great burdens on the population's health and, consequently, the economy (Hassan, 1985; Luckin, 2000; Melosi, 2000; Alsan and Goldin, 2019).

At a global level, Nordhaus (1977) introduced economists to the threat of climate change, stressing the importance of fossil fuel combustion in generating carbon dioxide emissions. Over the past three decades, attempts have been made to quantity the damages to the economy and society from climate change. Integrated assessment models have fed these impacts back into our models of economic growth to show how climate change is and will be a constraint on raising GDP per capita (Nordhaus, 1991; Stern, 2006).

An important point to emphasise is that natural resources and ecological systems are providing goods and services for free. Costanza et al. $(1997 ; 2014)$ placed the value of the global ecosystem in 1997 at $\$(2015) 165$ trillion and at $\$(2015) 142$ trillion in 2011, declining due to land use changes. In that time, the global world product increased from just under \$(2015)50 trillion to \$(2015)74 trillion in 2011 (World Bank, 2018). To replace these systems artificially with physical and human capital (as would mostly be needed on other planets) would be extremely costly. Thus, harming or disrupting the ecological 
systems on Earth would reduce the quantity and reliability of the supply system and the goods and services supplied, generating major burdens on the economy and society. Thus, correcting the market failures associated with the provision of natural resources and ecosystem services is critical to long run economic growth.

\section{GREEN GROWTH}

Fortunately, there is an increasing realisation that taking account of natural capital assets is indeed a prerequisite to ensuring long run economic growth (OECD, 2011). Most recently, this has come in the form of 'green growth'. While there are many different interpretations of this concept, the OECD (2011) proposes that green growth 'foster[s] economic growth and development, while ensuring that natural assets continue to provide the resources and environmental services on which our well-being relies.'

Consequently, this desired economic growth and development path should ensure that natural capital is maintained, enhanced and, if relevant, rebuilt. This is because, as stressed above, natural capital is seen as a vital factor of production, generating economic and social wellbeing. This investment in natural capital is particularly important for poorer populations, who lean heavily on these natural resources and ecosystem services for their livelihoods and wellbeing.

UNEP (2011) sees green growth as a process in which human wellbeing and social equity is improved, while significantly reducing environmental risks and ecological scarcities. This social dimension connects the concept of green growth to the earlier objectives of sustainable development. The Brundtland Report recommended that sustainable development 'meets the needs of the present without compromising the ability of future generations to meet their own needs' (UN, 1987). Thus, the desired path still seeks to maintain a balance between the three pillars of the economic, social and environmental development.

A key feature of green growth is that economic agents in expanding and developing economies should take account of natural capital, as well as social capital, when decisions are made. A central argument for governments selecting a green growth strategy is that taking account of natural capital will avoid the long run erosion of the foundations of economic growth and social wellbeing, mentioned earlier. In some cases, it might be immediately profitable and socially advantageous. In other cases, it might be a little more costly and lower return in the short run; however, the long run benefits of protecting the foundations of economic growth and social wellbeing make this additional investment worthwhile, at least from the public, if not the private, decision-maker.

The general consensus is that there is much to be gained from generating green growth. This was most recently emphasised in a report by the Business and Sustainable Development Commission (BDSC, 2017). It argued that Asian cities are especially wellpositioned to benefit from ensuring their economies grow in a 'green' way and target the global sustainable development goals (SDGs). The report noted that this would involve improving air and water, designing better buildings and public spaces, investing in lowcarbon transport, using natural resources more efficiently, and generating less waste. It estimated that Asian cities could gain $\$ 1.5$ trillion per year by 2030 , create tens of millions of new jobs, and improve the quality of life for their inhabitants. However, these returns 
depended on governments and businesses investing in sustainable cities and prioritising green growth over high-carbon alternatives.

A host of international organisations, including the World Bank, the Organisation of Economic Co-operation and Development (OECD) and the United Nations Environment Program (UNEP) have strongly supported the promotion of green growth strategies. They have sought to support the intellectual foundations for its promotion at the national level (Hallegatte, 2011). With considerable support from the South Korean government, the creation of a new international organisation with the prime objective of promoting green growth and advising governments on the appropriate policies and legislation, the Global Green Growth Institute (GGGI), reflects this increased international recognition, support and capacity.

In practice, policies related to green growth seek to achieve the objectives of raising incomes and employment levels while reducing pollution (particularly related to carbon dioxide emissions) and damage to ecosystem services and biodiversity, and increasing resource and energy efficiency. In order to achieve these objectives, two issues need to be addressed: long run improvements in resource efficiency and transitions away from polluting resources and technologies. These will be briefly considered in a long run perspective, focusing on energy use - although it should be clear that green growth applies to other materials and resources, too.

\section{LONG RUN IMPROVEMENTS IN RESOURCE AND ENERGY EFFICIENCY}

By reducing the input of resources required to generate a particular output, major investments in energy efficient technologies are central to tackling climate change issues. To preserve natural capital in the process of economic development, technological, as well as managerial and institutional, innovation will play an important role in decreasing the impact on the environment. They can also be sources of welfare gains to consumers (Fouquet, 2018). Finally, they may also be a source of green growth, although the nature of technological change and the crowding-out effect of innovation policies need to be considered carefully (Smulders and De Nooij, 2003).

In addition, this innovation may generate long run economic growth opportunities by reducing the costs of production. Looking at the history of the relationship between energy technology and economic growth, there is evidence that major improvements in energy efficiency appeared to have had major influences on economic growth and development, including possibly changing the nature of production and consumption processes (Fouquet, 2008). Indeed, Toman and Jemelkova (2003) emphasise the importance of energy services - such as heating, power and transport - in driving economic development. They show that energy services can affect economic development through a number of different channels, and that these effects can change at different levels of economic development. In other words, the energy services that will kick-start and drive periods of economic growth and development tend to change over time. Thus, it is worth considering which energy services have the potential to kick-start and to push forwards a New Industrial Revolution, and what transformations in the global economy they are likely to stimulate.

It is important to appreciate that the improvements in efficiency can be slow to 
unfold. For instance, the average efficiency of stationary power in the United Kingdom was transformed by a series of scientific and technological innovations that began four hundred years ago, before the First Industrial Revolution. These processes culminated in a doubling of energy efficiency in the provision of power services during the twentieth century (Fouquet, 2008). While the future is unlikely to unfold in the same way as the past did, one might use this evidence (coupled with knowledge of the major investments in efficiency improvements) to anticipate that energy efficiency improvements related to power services (whether computers, appliances, lighting, as well as in industrial activities) will double during the twenty-first century. In a similar way, we might anticipate even greater improvements in efficiency in transport services, since it improved six-fold during the twentieth century. Thus, historical experiences indicate that we should not be surprised by and even arguably expect dramatic transformations in the relationship between input and outputs of the global energy system over the next century.

This is also likely to have major implications for the global economy. Indeed, industrialised economies have been locked into fossil fuel-based energy systems for centuries and this has imposed substantial economic costs, particularly related to price shocks (Van de Ven and Fouquet, 2017). More generally, efforts to lower energy intensity will have favourable long run impacts related to vulnerability to energy price shocks, inflation, trade balances, political pressures from energy companies and environmental pollution (Fouquet, 2016).

\section{TRANSITIONS TO LOW CARBON ECONOMIES}

The second challenge to achieving green growth is for economies to reduce their rates and absolute levels of pollution. Ultimately, economic growth driven by fossil fuels is 'unsustainable'. Given that coal, petroleum and natural gas are non-renewable resources, they could not act as the principal fuels in the long run. However, humanity's ability to discover, extract and use fossil fuels - nearly 0.5 trillion tonnes of oil equivalent (see Figure I.1) since the beginning of the Industrial Revolution - indicates that this limit can be pushed far into the twenty-first century or even beyond.

More pressing is that fossil fuel use has led to 1.2 trillion tonnes of carbon dioxide emissions. These past and future global emissions, along with other greenhouse gas emissions, are threatening to intensify climate change. This threat means that fossil fuels, without worldwide carbon capture and sequestration mechanisms or successful geo-engineering projects, will impose a rising burden on the atmosphere. As a consequence, the fossil fuel energy system will be only a temporary phase in the history of global economic development.

Nevertheless, it is important to appreciate that the 0.5 trillion tonnes of oil equivalent of fossil fuels has been critical in enabling the global average GDP per capita to rise from \$(2015)1100 in 1700 to \$(2015)16 200 in 2015 (Bolt and Van Zanden, 2014; Index Mundi, 2018). There were early attempts to develop and transform individual economies in Europe and in Asia; however, it was only the development of the fossil fuel energy system, ushered in by the First Industrial Revolution, that allowed economies across the world to grow for the last 250 years (Allen, 2009). Thus, despite current concerns, it is important to remember to value the dramatic improvements in living standards that the fossil fuel energy system helped achieve. 


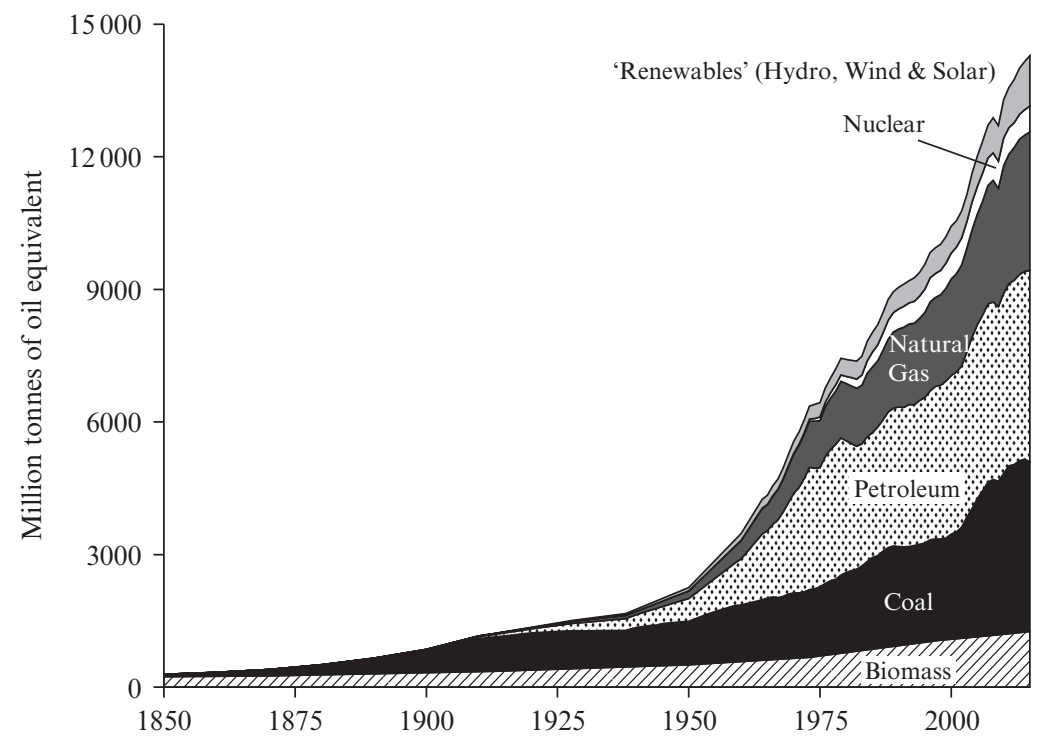

Source: Etemad et al. (1991); Maddison (2003); BP (2017).

\section{Figure I.1 Global primary energy consumption, 1850-2016}

However, given the unsustainable and temporary nature of the fossil fuel energy system, it is equally vital to ensure that this wealth and value be used to ensure that our current living standards are sustainable. It would be wasteful if, once the global economy ceased using fossil fuels, either because of limited resources or atmospheric constraints, our standards of living dwindled back to the levels experienced before the Industrial Revolution, as Angel Gurria suggests. Thus, the fossil fuel energy system must be the springboard for another energy system and a new era in economic development.

An important question is whether fossil fuels and low carbon energy sources can be substitutes for one another in the production process. Indeed, some characteristics may limit the ability to substitute between renewable and fossil fuels. For instance, the cost structure is very different: whereas fossil fuels have relatively low fixed costs and higher variable costs, low carbon generation (whether wind, solar or nuclear) tends to have high installation costs and low variable costs. The difference affects the returns and risks from low carbon investments. Furthermore, the marginal productivity of investment in clean capacity may be declining, particularly for wind and solar - that is, investment is likely to be installed first in locations with high potential for wind or solar, say, and then in areas with lower potential. Finally, transportability of power is currently limited by storage devices. Nevertheless, the limited empirical evidence supports the view that there exists a high elasticity of substitution between clean and dirty energy inputs (Papageorgiou et al., 2017). Although one should be concerned about the limitations going forward, this evidence implies that green growth is possible.

With this in mind, it is promising that the 2010s were a tipping point for renewable energy sources, particularly for wind and solar power. The costs of generating electricity from these sources have declined rapidly in the last decade (see Figure I.2). In tandem, 


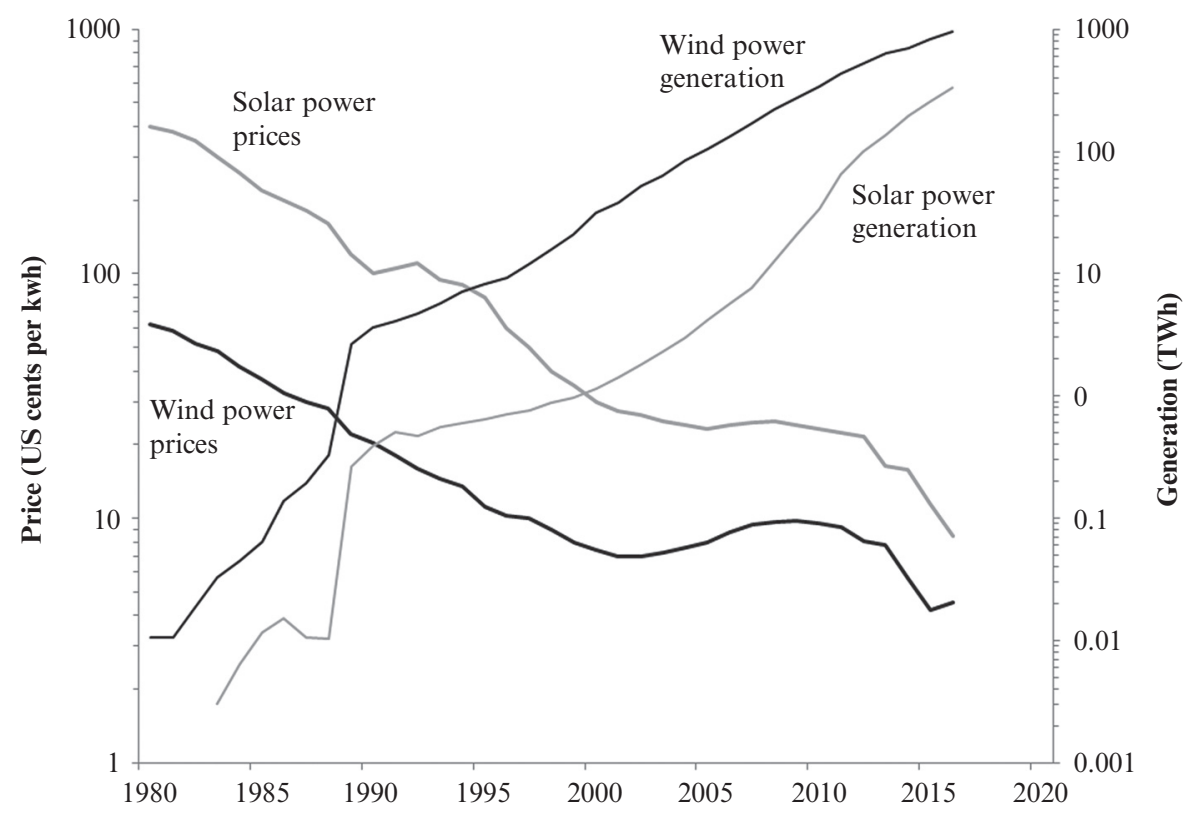

Source: Prices: Nemet (2006), DoE (2015), Frankl (2017); Generation: BP (2017).

Figure I.2 Price and global generation of wind and solar power, 1980-2016

investment, capacity and generation have increased dramatically: wind power production has risen seven-fold, and solar power has increased 60-fold in the last ten years (see Figure I.2).

The declines in costs imply that renewable power sources are competing with fossil fuel-based power, and the rise in capacity is associated with an increase in the share of electricity generated from low carbon sources. As a result, economic growth is becoming greener. In addition, if costs continue to decline, renewable energy sources offer the prospect of reducing the average cost of power production, stimulating a major new phase of economic growth.

Until now, few economies can claim to be low carbon. There are exceptional cases, where resource availability, such as Iceland and Costa Rica, or strong political will, such as Germany and Denmark, exist. Nevertheless, they pave the way, and other economies can learn from their choices and their experiences, providing valuable information and knowledge, thus reducing the costs of transitioning towards low energy sources and transforming towards green growth.

\section{GREEN GROWTH AND STRUCTURAL TRANSFORMATION}

As suggested, green growth could be the key to a new phase of economic growth. Ironically, climate sceptics argue that addressing climate change will be too great a burden for the economy, when the opposite may be more accurate. First, a failure to stabilise the climate 
is likely to radically alter average temperatures and rainfall, intensify destructive weather events and increase uncertainty. It will also lead to rising sea levels (with increased land scarcity) and changes in the supply of ecosystem services. These will generate new local, regional and global political tensions. As carbon dioxide and greenhouse gas emissions increase, climate change will continue and the problems will accelerate.

Second, failure to transition away from the fossil fuel energy system will imply a status quo. As noted earlier, structural transformation is necessary for economic and social advancement. Without it, powerful vested interests capture increasing shares of the gains from economic production and exchange. This can lead to increasing inequality and ultimately social tensions (Piketty, 2014).

Major energy technologies and transitions of the past have been fundamental to major phases of economic growth in history (Freeman and Louça, 2001). The growth in markets for energy sources were closely linked to other technologies and industries. These energy systems (such as the 'coal block', consisting of coal, steam engines, and the iron industry in the late eighteenth and early nineteenth centuries, then electricity and mass production and oil and the internal combustion engine in the late nineteenth and twentieth centuries) created mutual markets for each other's products, achieving economies of scale and declining costs. The implications of energy transitions depended on the market suction and market widening created by the links between, for example, oil demand and the car, and oil demand and oil tankers, respectively (Kander et al., 2013). Thus, energy transitions have both been dependent on these broader economic transformations that take decades to unfold and catalysts of these economic transformations (Perez, 2002).

One potential new cluster - or 'development block' (Enflo et al., 2007) - links new energy systems with the radical changes driven by information and communication technology (Fouquet, 2017). A major challenge is to identify and understand the interlinkages and synergies that can occur. Certainly, ICT has been the source of major economic growth and, until recently, energy did not play an important role in this development (World Bank, 2012). However, the sheer amount of information exchanged and stored is generating a huge growth in data centres. These data centres in turn are demanding large amounts of energy to drive them and cool them (Koomey, 2008; Koomey et al., 2011; 2013). Key ICT companies, such as Google, Apple and Microsoft, have adopted low-carbon strategies installing or securing renewable energy to cover their power requirements. This locks the industry into a low carbon trajectory and sends a signal to other industries. In addition, from smart meters to blockchains to peer-to-peer networks, ICT will play a key role in the development of renewable energy sources. Thus, the emergence of a cluster linking ICT with renewables may be the catalyst and engine of the next industrial revolution.

More generally, green growth - associated with radical improvements in energy efficiency and transitions to low carbon energy sources - offers a new potential source of structural transformation. This would occur through the synergies created by new developments related to infrastructure, technologies, entrepreneurship and business models, financing, employment, and geopolitics, as well as new social, cultural and intellectual movements.

To achieve these transformations, governments will need to create the incentives and catalyse these transformations. Yet, as the theoretical model in Acemoglu et al. (2012) and the discussion on industrial clusters suggest, the institutional support will not be needed in the long run. Instead, it will only be required to place the economy on the new 'green growth' pathway. Afterwards, green growth will be inevitable and ubiquitous - in 
the same way that an economy without slave or child labour is taken for granted, almost everywhere. However, to get onto that path, leaders need to have the vision to identify the desired objectives, the clarity to understand how this can be achieved, and the strength to keep the balance between requirements of the dynamic newcomers and the demands of the powerful incumbents.

\section{THE PURPOSE AND OUTLINE OF THE $H A N D B O O K$}

With this discussion in mind, the purpose of this Handbook is to provide a better understanding of the concept of green growth, and lessons from the experiences of green transformations after roughly one decade of ambitious stimulus packages and reforms. It seeks to address the questions raised at the beginning of this chapter. To do so, the Handbook is divided into five parts on the growth strategy, the potential for green growth and its impacts, the drivers of green growth, the lessons from specific green transformations and how green growth links with the broader current structural transformations.

Part I of this Handbook addresses the debate about growth head-on. Inviting three prominent voices in the debate about green growth, this part offers an opportunity to question the importance of achieving economic growth, and its relationship with environmental damage.

Lipsey starts by identifying that green growth and no-growth advocates agree on the importance of addressing environmental problems, but disagree on how to address them. While the former camp recommends finding environmentally-benign growth trajectories, the latter group argues that an environmental catastrophe is inevitable unless economic growth is halted. Within this debate, Lipsey proposes that the optimal strategy is to advance with a set of green growth policies, and only switch to a no-growth strategy if the former fails to deliver environmental improvements.

Victor and Sers highlight the challenges facing an economy seeking to grow economically and pursue a transition away from fossil fuels. They focus on some of the macroeconomics challenges of greenhouse gas emission reduction. They stress the risk of economies getting caught in an 'energy-emissions trap', in which the transition to renewable energy requires increases in fossil fuel consumption, and ask whether green growth can avoid this risk. They also emphasise the distinction between green growth as a short term or long term strategy, and question whether green growth can be a long term strategy, particularly when expanded beyond the specific objectives of mitigating carbon dioxide emissions to the objectives of addressing multiple planetary boundaries, such as biodiversity and ecosystems.

Van den Bergh and Drews also explore the debate about the relationship between economic growth and environmental quality. They, however, argue that focusing on economic growth per se may limit the potential to maximise social wellbeing. They explain that while some growth trajectories may coincide with improving wellbeing, others will not. Thus, they suggest that an 'a-growth' strategy - that is, one that is neither for nor against growth - is the most desirable. Instead, they propose the objective should be to find a balance between all aspects of social welfare.

Part II of this Handbook investigates the features of green growth, including what the wider implications will be, for instance, for employment and inequality. In the first 
chapter, Aghion, Hepburn, Teytelboym and Zenghelis emphasise the importance of getting on the correct pathway. Economies tend to get locked into systems of production, distribution and consumption. The authors highlight that history and expectations matter greatly in determining eventual outcomes, and it is important in fostering expectations and creating innovation that will lock the economy into a green and low-carbon economic system. They note that to do so it will be important to subsidise clean innovation, and that delaying the subsidisation will increase the costs of a transition towards a low carbon economy.

Bowen reviews in considerable detail the literature on the relationship between environmental degradation or improvements and economic growth. He proposes a number of channels through which the environment is important for the economy, including saving rates, the rate of accumulation of manufactured, human and knowledge capital, and the rates of depletion of exhaustible resources and potentially renewable resources and pollution sinks. He notes that theoretical models tend to focus on the role of resourceaugmenting technical progress in the long run, given the environmental constraints. The author then turns to empirical studies, suggesting that the macroeconomic evidence of the impact of these environmental constraints on productivity growth have been modest, so far. He finds that the microeconomic studies (with partial equilibrium frameworks) tend to find larger impacts. He also reviews long run and historical experiences - with important lessons of environmental damage and climate change playing a pivotal role in economic decline. Nevertheless, he concludes that assessing the current and future scale of these influences is difficult in practice, and needs to be done on a case-by-case basis with creative empirical strategies to identify a causal relationship.

The next two chapters turn to empirical measurements of the relationship between resource efficiency and economic growth. Both Turner and Katris, and Sue Wing and Timilsina investigate the question of the impact of technological adoption - and, in particular, energy efficiency improvements - on economic growth. Turner and Katris focus on industrialised economies and emphasise the difficulty of generalising, confirming that the economic growth potential needs to be identified on a case-by-case basis. Focusing on improvements in developing economies, Sue Wing and Timilsina present a new method for combining bottom-up and top-down approaches to help answer this question. They highlight the need for policy-makers to identify cases where energy efficiency improvements lead to large reductions in costs, as potential sources of boosting economic growth. Indeed, even apparently 'no-regrets' energy efficiency investments can impose substantial macroeconomic costs on the economy if output is forgone with the diversion of capital away from high-return production activities and toward lower-return energy saving activities, with modest environmental benefits. Thus, caution is needed.

Bowen analyses the impact of green growth on inequality. He argues that distributional impacts can occur from relative price changes affecting households, changes in aggregate demand, the adoption of new technologies with different labour and capital requirements, and factor market adjustments in response to the structural changes induced by policies. Indeed, he stresses that employment can be strongly affected by national green growth policies and how labour markets react depends on an economy's openness to trade, its endowments of raw materials and its macroeconomic situation. He proposes that the distributional impacts can be minimised by careful consideration of the revenue from environmental taxation, labour market policies and the welfare system. 


\section{Handbook on green growth}

What is required to generate green growth? Part III of this volume investigates the key determinants of green growth: structural transformation, infrastructure, technological change, finance, networks of entrepreneurs, and government policy. Together, a better understanding of these factors will paint a clearer picture of how to initiate green growth and overcome challenges.

Ahmad, Neuweg and Stern discuss the importance of structural transformation and infrastructure in driving green growth. The chapter focuses on the critical role China will play in determining whether many economies follow a pathway generating green growth or one producing fragile carbon-intensive growth. The authors highlight that, partly through structural transformations needed at a domestic level and through major international infrastructure and trade initiatives, such as the Belt and Road Initiative, China will stimulate the potential for growth and structural transformation in numerous other economies, particularly in Asia and Africa. However, the authors stress that the selection of projects is crucial. Many may involve the development of major coal extraction and distribution infrastructure, leaving these economies vulnerable to stranded high-carbon assets. Alternatively, investments could be made in developing a greener, more sustainable energy infrastructure. The authors also underline that, although these links with China will be important, they will not be sufficient to ensure inclusive, sustainable development. Indeed, carefully crafted national policies, associated with further infrastructure investment and tax reforms, will be needed for these economies. Thus, the Chinese initiatives and transformations create a critical juncture, in which these economies can leap onto a new greener growth pathway; however, they will need to seize the opportunity or risk sliding back into anachronistic and unsustainable types of growth.

Dechezleprêtre, Martin and Bassi focus on research and development, and summarise the evidence related to stimulating low-carbon innovation. For instance, they find that market-based instruments tend to favour innovation in technologies that are closest to the market. The implication is that these policies need to be accompanied by direct support, such as public funding of R\&D and feed-in tariffs, for emerging technologies that will be essential to long-term emissions reduction targets. In the extended debate about the appropriate instrument for promoting renewable technology development, the realisation that they are complements rather than substitutes is an important lesson. Finally, increasing public support for low-carbon R\&D may be politically attractive because low-carbon innovations have larger economic benefits than the carbon-intensive technologies they replace.

Semieniuk and Mazzucato assess the current state of financing green growth in the energy sector. They identify the crucial role that public financing has played in R\&D for energy transitions in the past and could do in the future. They warn that, despite considerable investment in green energy, financing is insufficient - and partially misdirected - to ensure a low carbon transition on timescales consistent with current climate change mitigation targets.

Colombelli and Quatraro explore the role of start-ups in green technological development. They identify the key role networks of entrepreneurs play in creating start-ups. Based on the knowledge spillovers theory of entrepreneurship, the authors examine how local knowledge affects the generation of green start-ups. They conclude that green start-ups are associated with higher levels of variety, pointing to the relevance of diverse and heterogeneous knowledge sources, but in related and complementary technological 
fields. Carvalho highlights the importance of geography in influencing the effectiveness of green industrial policies. The chapter shows how the spatial dynamics of technologies and industrial activities can influence national green growth opportunities. In fact, she argues that maximising economic value within the economy does not always occur through domestic manufacturing, even though this may clash with the nationalist perceptions of techno-industrial activity. Depending on the stage of development of the technology and a country's own comparative advantages, she proposes that the best strategy might involve importing cheaper green technologies. Thus, effective green industrial policy requires a careful understanding of the specific context of technologies and trade opportunities.

Part IV of this Handbook focuses on individual experiences of green growth and transformation. Here, there is an emphasis on Asian, Latin American and African economies. This is deliberate, because much of the empirical analysis inevitably focuses on European and North American economies, and is already covered in some detail in previous chapters, such as Bowen's, Dechezleprêtre, Martin and Bassi's and Cavalho's reviews of the predominantly industrialised economy literature, Turner and Katris on Scotland, Sue Wing and Timilsina on Georgia and Armenia, Semieniuk and Mazzucato on case studies in Iceland, France, Norway and the USA, and Colombelli and Quatraro on Italy. Hence, the emphasis on mostly industrialising and developing economies seems justified.

Matthews examines the Chinese rise to prominence in the pursuit of green growth. Indeed, he offers an interesting alternative model of economic development - one that involves a great deal of planning, coordination and coercion. At the same time, he shows that China's pathway was guided by its concerns about resource scarcity and the Chinese aversion to geopolitical tensions. Furthermore, he explains how China stumbled upon the notion of 'ecological civilization' as a result of the massive domestic damage caused by air pollution from coal combustion.

Lee reviews the history of green growth in South Korea - the only industrialised economy case study in this part. He shows how the ability to generate green growth is dependent on politicians' preferences and the momentum this creates. For instance, a first leader identified the importance of green growth and undertook major reforms to ensure its success. A second leader, seeking to distance the government from the predecessor, removed references to green growth, and instead focused on the creative knowledge economy. However, Lee shows that many of the original green growth policies have been kept, or simply renamed. Furthermore, as the chapters in Part V of this Handbook propose, these two politicians may have been bringing together two major trends related to economic growth. Thus, it makes this case particularly exciting to follow.

As India is likely to grow rapidly and become the most populous nation in the world within the next decade, it is valuable to understand its energy intensity and carbon intensity trajectory. Parry, Mylonas and Vernon identify the options available for Indian energy policy-makers to minimise fossil fuel consumption and carbon dioxide emissions. They find that the most effective option is to increase the existing coal tax, which could potentially generate economic benefits, reduce deaths due to air pollution and limit carbon dioxide emissions, while being regressive and, thus, increasing inequality.

Lederer, Wallbott and Urban present a valuable framework for analysing green transformations in developing economies, with the case studies of Costa Rica and Vietnam. Central lessons for other countries are that Costa Rica reversed its pathway of deforestation by reforesting the land and then starting to address the criticisms of its 
development by generating more genuinely green growth, and that Vietnam was focused on post-conflict restoration and economic development. In other words, these countries - rather than having chosen easy pathways - made difficult choices that went against powerful vested interest groups within the country. This makes the decisions (and possibly the experiences) particularly relevant to other (smaller) countries considering taking a pathway involving green transformation.

Bishop and Brahmbhatt provide a comprehensive and detailed review of green growth and potential related policies in African economies. They stress that economic transformations will be pivotal to pushing forward the 'African Growth Miracle'. Given the wide diversity of economies and natural resources, they caution against a single 'African Model' of green growth. Nevertheless, the authors propose that many African economies have the potential to transform themselves to generate substantially greener growth related to agriculture, energy, cities, as well as in industry or services. They remind the reader that the biggest challenge will be policy makers creating the required incentives given the speed and scale of the transformations underway, while balancing interests and minimising inequality.

Part V considers where a low carbon pathway may take us. Much of this Handbook has focused on addressing a negative environmental externality, carbon dioxide emissions and the associated climate change. However, economic growth needs to be focusing on positive, desirable and valuable objectives. Thus, the final chapters explore what form of green economic growth will unfold in the future.

Perez identifies and brings together two major trends in economic growth: the knowledge economy and green growth. Together, she envisions that 'smart green growth' has the potential to generate strong and sustainable economic expansion and development. She uses lessons from periods of rapid economic growth to understand how financial markets may deliver a new golden age.

Quah explores the transition towards a dematerialised economy, driven by the expansion of the digital sphere. In particular, he highlights that it has the potential to generate both considerable economic growth and inequality. This was a piece originally written in the mid-1990s, but never published. With the momentum of the digital economy and the rise of inequality, it addresses issues more relevant today than ever. Thus, in order to give this chapter a new lease of life and to re-emphasise the points made, it is now published.

Finally, Fouquet and Hippe revisit the point made by Perez on 'smart green growth' and seek to understand the origins of this transformation, which represents an opportunity to avoid remaining locked into an anachronistic type of economic growth and reducing 'the risks of irreversible changes that could endanger two centuries of rising living standards' (OECD 2012, p.1). They show that economic growth in history was driven by the development of energy markets (and boosted by energy transitions), particularly between the eighteenth century and the Oil Shocks of the 1970s, and driven by the development of information, human capital and knowledge (and related transitions), which have also been underway for a long time but becoming more dominant today. They argue that there has been a very long run transition in the fundamental drivers of economic growth - with a shift from energy resources to knowledge - which is only now becoming apparent. 


\section{REFERENCES}

Acemoglu, D. and Robinson, J. (2012). Why Nations Fail? The Origins of Power, Prosperity and Poverty. New York, NY: Crown Business.

Acemoglu, D., Aghion, P., Bursztyn, L. and Hemous, D. (2012). The environment and directed technical change. American Economic Review, 102(1): 131-66.

Allen, R.C. (2009). The British Industrial Revolution in Global Perspective. Cambridge: Cambridge University Press.

Alsan, M. and Goldin, C. (2019). Watersheds in child mortality: the role of effective water and sewerage infrastructure, 1880 to 1920. Journal of Political Economy, 127(2).

Anderson, R.V. and Gallman, R.E. (1977). Slaves as fixed capital: slave labor and southern economic development. The Journal of American History, 64(1): 24- 46.

Auty, R.M. (2001). Resource Abundance and Economic Development. Oxford: Oxford University Press.

Badia-Miró, M. and Ducoing, C.A. (2015). Long-run development in Chile and natural resource curse: linkages, policy and growth, 1850-1950. In Badia-Miró, M., Willebald, H. and Pinilla, V. (eds), Natural Resources and Economic Growth: Learning From History. New York, NY: Routledge, pp. 204-25.

Badia-Miró, M., Pinilla, V. and Willebald, H. (2015). Natural Resources and Economic Growth: Learning from History. London: Routledge.

Barbier, E.B. (2005). Natural Resources and Economic Development. Cambridge: Cambridge University Press.

Barbier, E.B. (2010). Green stimulus, green recovery and global imbalances. World Economics, 11(2): 149-75.

Barbier, E.B. (2011). Scarcity and Frontiers: How Economies Have Developed Through Natural Resource Exploitation. Cambridge: Cambridge University Press.

Barbier, E.B. (2013). Is a global crisis required to prevent climate change? A historical-institutional perspective. In Fouquet, R. (ed.), Handbook on Energy and Climate Change. Cheltenham, UK and Northampton, MA, USA: Edward Elgar Publishing.

Barham, B. and Coomes, O. (1994). Wild rubber: industrial organisation and the microeconomics of extraction during the Amazon rubber boom (1860-1920). Journal of Latin American Studies, 26(1): 37-72.

BDSC (2017). Better Business, Better World: Sustainable Business Opportunities in Asia. London: Business \& Sustainable Development Commission.

Bértola, L. (2015). Welfare states and development patterns in Latin America. In Badia-Miró, M., Willebald, H. and Pinilla, V. (eds), Natural Resources and Economic Growth: Learning from History. New York, NY: Routledge, pp. 140-59.

Bolt, J. and Van Zanden, J.L. (2014). The Maddison Project: collaborative research on historical national accounts. Economic History Review, 67(3): 627-51.

Bowen, A. and Hepburn, C. (2014). Green growth: an assessment. Oxford Review of Economic Policy, 30(2): 407-22.

BP (2017). Statistical Review of World Energy 2015. London: BP plc.

Cipolla, C.M (1962). The Economic History of World Population. London: Pelican Books.

Clay, K. (2010). Natural resources and economic outcomes. In Rhode, P., Rosenbloom, J. and Weiman, D. (eds), Economic Evolution and Revolutions in Historical Time. Stanford, CT: Stanford University Press.

Costanza, R., d'Arge, R., De Groot, R., Farber, S., Grasso, M., Hannon, B., Limburg, K. et al. (1997). The value of the world's ecosystem services and natural capital. Nature, 387(6630): 253-60.

Costanza, R., De Groot, R., Sutton, P., Van der Ploeg, S., Anderson, S.J., Kubiszewski, I., Farber, S. et al. (2014). Changes in the global value of ecosystem services. Global Environmental Change, 26: 152-8.

Dasgupta, P.S. and Heal, G.M. (1979). Economic Theory and Exhaustible Resources. Cambridge: Cambridge University Press.

Deaton, A. (2013). The Great Escape: Health, Wealth, and the Origins of Inequality. Princeton, NJ: Princeton University Press.

Diamond, J. (2005). Collapse: How Societies Choose to Fail or Survive. London: Allen Lane.

DoE (2015). Revolution. . now: the future arrives for five clean energy technologies. Accessed at https://www. energy.gov/sites/prod/files/2017/05/f34/Revolution $\% 20$ Now $\% 202016 \% 20$ Report_2.pdf.

Drabble, J.H. (2000). An Economic History of Malaysia, c.1800-1990: The Transition to Modern Economic Growth. London: Macmillan.

Enflo, K., Kander, A. and Schön, L. (2007). Identifying development blocks: a new methodology implemented on Swedish industry 1900-1974. Journal of Evolutionary Economics, 18(1): 57-76.

Engerman, S.L. (1995). The Atlantic economy of the eighteenth century: some speculations on economic development in Britain, America, Africa, and elsewhere. Journal of European Economic History, 24(1): 145-75.

Etemad, B., Luciani, J., Bairoch, P. and Toutain, J.-C. (1991). World Energy Production 1800-1985. Geneva: Librairie DROZ.

Fouquet, R. (2008). Heat, Power and Light: Revolutions in Energy Services. Cheltenham, UK and Northampton, MA, USA: Edward Elgar Publishing. 
Fouquet, R. (2011). Divergences in long run trends in the prices of energy and energy services. Review of Environmental Economics and Policy, 5(2): 196-218.

Fouquet, R. (2016). Path dependence in energy systems and economic development. Nature Energy, 1(8): 16098.

Fouquet, R. (2017). Make low-carbon energy an integral part of the knowledge economy. Nature, 551(7682): S141.

Fouquet, R. (2018). Consumer surplus from energy transitions. The Energy Journal, 39(3): 167-88.

Frankl, P. (2017). Renewable markets and system integration: status and forecasts. Paper presented at The European Forum for Renewable Energy Sources: Annual High-Level Experts Conference 2017, Brussels, 17 October.

Freeman, C. and Louça, F. (2001). As Time Goes By: From the Industrial Revolutions to the Information Revolution. Oxford: Oxford University Press.

Friedman, B. (2005). The Moral Consequences of Economic Growth. New York, NY: McGraw-Hill.

Galor, O. (2011). Inequality, human capital formation, and the process of development. In Hanushek, E.A., Machin, S. and Woessmann, L. (eds), Handbook of the Economics of Education, Vol. 4, Oxford: Elsevier, pp. 441-93.

Goldin, C. and Katz, L.F. (1998). The origins of technology-skill complementarity. Quarterly Journal of Economics, 113(4): 693-732.

Hallegatte, S. (2011). From Growth to Green Growth: A Framework. Washington, DC: World Bank.

Hassan, J. (1985). The growth and impact of the British water industry in the nineteenth century. Economic History Review, 38(4): 531-47.

Hillbom, E. (2015). Botswana: caught in a natural resource trap. In Badia-Miró, M., Willebald, H. and Pinilla, V. (eds), Natural Resources and Economic Development. Learning from History, New York, NY: Routledge, pp. 77-99.

Horrell, S. and Humphries, J. (1995). The exploitation of little children: child labor and the family economy in the industrial revolution. Explorations in Economic History, 32(4): 485-516.

Index Mundi (2018). World GDP per capita (PPP). Accessed at https://www.indexmundi.com/world/gdp_per_ capita_(ppp).html.

Johnson, A.S. (1909). Introduction to Economics. Boston, MA: D.C. Heath \& Co.

Kander, A., Malanima, P. and Ward, P. (2013). Power to the People: Energy in Europe Over the Last Five Centuries, Princeton, NJ: Princeton University Press.

Koomey, J.G. (2008). Worldwide electricity used in data centers. Environmental Research Letters, 3(3): 034008.

Koomey, J.G., Matthews, H.S. and Williams, E. (2013). Smart everything: will intelligent systems reduce resource use? Annual Review of Environment and Resources, 38: 311-43.

Koomey, J.G., Berard, S., Sanchez, M. and Wong, H. (2011). Implications of historical trends in the electrical efficiency of computing. IEEE Annals of the History of Computing, 33(3): 46-54.

Luckin, B. (2000). Pollution in the city. In Clark, P., Palliser, D.M. and Daunton, M.J. (eds), The Cambridge Urban History of Britain. Vol. III 1840-1950. Cambridge: Cambridge University Press, pp. 207-28.

Lundahl, M. (1998). Staples trade and economic development. In Lundahl, M. (ed.), Themes of International Economics. Boston, MA: Ashgate Publishing, pp.45-68.

Maddison, A. (2003). Growth accounts, technological change, and the role of energy in western growth. In Cavaciocchi, S. (ed.), Economia e Energia. Florence: Le Monnier.

Malthus, T.R. (1798). An Essay on the Principle of Population as it Affects the Future Improvement of Society. London: Ward Lock.

Matus, K., Nam, K., Selin, N.E., Lamsal, L.N., Reilly, J.M. and Paltsev, S. (2012). Health damages from air pollution in China. Global Environmental Change, 22: 55-66.

McCloskey, D. (2006). The Bourgeois Virtues: Ethics for an Age of Commerce. Chicago, IL: University of Chicago Press.

Melosi, M.V. (2000). The Sanitary City: Urban Infrastructure in America from Colonial Times to the Present. Baltimore, MD: Johns Hopkins University Press.

Mokyr, J. (2002). The Gifts of Athena: Historical Origins of the Knowledge Economy. Princeton, NJ: Princeton University Press.

NCE (2014). Better Growth, Better Climate: The New Climate Economy Report. Washington, DC: New Climate Economy.

Nemet, G.F. (2006). Beyond the learning curve: factors influencing cost reductions in photovoltaics. Energy Policy, 34(17): 3218-32.

Nordhaus, W.D. (1977). Economic growth and the climate: the carbon dioxide problem. American Economic Review, 67(1): 341-6.

Nordhaus, W.D. (1991). To slow or not to slow: the economics of the greenhouse effect. The Economic Journal, 101(4): $920-37$.

North, D. (1990). Institutions, Institutional Change, and Economic Development. Cambridge: Cambridge University Press. 
OECD (2011). Towards Green Growth. Paris: Organisation for Economic Co-operation and Development.

OECD (2012). OECD Environmental Outlook to 2050: The Consequences of Inaction. Paris: Organisation for Economic Co-operation and Development.

OECD (2018). The Long View: Scenarios for the World Economy to 2060. Paris: Organisation for Economic Co-operation and Development.

Olson, M. (1982). The Rise and Decline of Nations. New Haven, CT: Yale University Press.

Papageorgiou, C., Saam, M. and Schulte, P. (2017). Substitution between clean and dirty energy inputs: a macroeconomic perspective. Review of Economics and Statistics, 99(2): 281-90.

Perez, C. (2002). Technological Revolutions and Financial Capital: The Dynamics of Bubbles and Golden Ages. Cheltenham, UK and Northampton, MA, USA: Edward Elgar Publishing.

Piketty, T. (2014). Capital in the Twenty-First Century. Cambridge, MA: Harvard University Press.

Ranestad, K. (2018). Knowledge-Based Growth in Natural Resource Intensive Economies: Mining, Knowledge Development and Innovation in Norway 1860-1940. London: Palgrave Macmillan.

Ricardo, D. (1817). On the Principles of Political Economy and Taxation. London: John Murray.

Robins, N., Clover, R. and Singh, C. (2009). A Climate for Recovery: The Colour of Stimulus Goes Green. London: HSBC Global Research.

Rodrik, D. (2013). Green Industrial Policy. Princeton, NJ: Princeton University Press.

Rubio-Varas, M. (2015). Oil illusion and delusion: Mexico and Venezuela over the twentieth century. In BadiaMiró, M., Willebald, H. and Pinilla, V. (eds), Natural Resources and Economic Development: Learning From History. New York, NY: Routledge, pp. 160-83.

Sanders, A.R.D. and Sandvik, P.T. (2015). Avoiding the resource curse? Democracy and natural resources in Norway since 1900. In Badia-Miró, M., Willebald, H. and Pinilla, V. (eds), Natural Resources and Economic Development: Learning From History. New York, NY: Routledge, pp. 313-38.

Sen, A. (1999). Development as Freedom. Oxford: Oxford University Press.

Schumpeter, J.A. (1942). Socialism, Capitalism and Democracy. New York, NY: Harper and Brothers.

Smulders, S. and De Nooij, M. (2003). The impact of energy conservation on technology and economic growth. Resource and Energy Economics, 25(1): 59-79.

Solow, R.M (1956). A contribution to the theory of economic growth. Quarterly Journal of Economics, 70(1): 65-94.

Solow, R.M. (1974). The economics of resources or the resources of economics. American Economic Review, 64(2): 1-14.

Stern, D.I. and Kander, A. (2012). The role of energy in the industrial revolution and modern economic growth. The Energy Journal, 33(3): 127-54.

Stern, N. (2006). The Stern Review: Report on the Economics of Climate Change. Cambridge: Cambridge University Press.

Stern, N. (2009). A Blueprint for a Greener Planet. London: The Bodley Head.

Toman, M.A. and Jemelkova, B. (2003). Energy and economic development: an assessment of the state of knowledge. The Energy Journal, 24(2): 93-112.

Toynbee, A.J. (1946). A Study of History. Abridgement of Vol I-III. Oxford: Oxford University Press.

UN (1987). Report of the World Commission on Environment and Development: Our Common Future. New York, NY: United Nations.

UNEP (2011). Towards a Green Economy: Pathways to Sustainable Development and Poverty Eradication. A Synthesis for Policymakers. Nairobi: United National Environment Program.

Van de Ven, D.J. and Fouquet, R. (2017). Historical energy price shocks and their changing effects on the economy. Energy Economics, 62: 204-16.

World Bank (2012). ICTs for Greater Development Impact - World Bank Group Strategy for Information and Communication Technology 2012-2015. Washington, DC: World Bank.

World Bank (2018). World Development Indicators. Washington, DC: World Bank.

Wright, G. and Czelusta, J. (2006). Resource-based growth past and present. In Lederman, D. and Maloney, W. (eds), Neither Curse nor Destiny: Natural Resources and Development. Stanford, CT: Stanford University Press. 